\title{
Anticardiolipin and Anti-/32 Glycoprotein I Antibodies in Pregnant Women with Severe Pre-Eclampsia
}

\author{
NABILA M. THABET, M.D.*; OSAMA BAKR, M.D.*; DIAA AL-DIN M. AL-NASHAR, M.D.**; \\ HEBA A. ABD EL-HAFEEZ, M.D. and MAHA G. ABD EL-KADR, M.Sc.* \\ The Departments of Clinical Pathology* and Obstetrics \& Gynecology**, Faculty of Medicine, Assiut University
}

\begin{abstract}
Background: APA have been associated with a number of obstetric complications however their role in the pathogenesis of preeclampsia has remained an issue of controversy.

Aim of the Study: 1- Detection of Anticardiolipin antibodies and Anti- 32 glycoprotein I antibodies in pregnant women with severe pre-eclampsia. 2- Estimation of the prevalence of APA in pregnant women with severe pre-eclampsia.

Patients and Methods: This is a case control study. Eighty pregnant women diagnosed of severe pre-eclampsia and twenty age-parity matched normal on-going pregnant women were recruited as participants for the study. Antiphospholipid antibodies were assayed using Dilute Russel Viper's Venom (DRVV) Lupus Anticoagulant (LA screen and confirm kits), Anticardiolipin Antibody (ACA) Enzyme Linked Immunosorbent Assay (ELISA) kits and Anti- 32 glycoprotein I antibodies ELISA-based test system were used.

Results: The prevalence of APLA in severe pre-eclampsia was $6.25 \%$, while none $(0 \%)$ of the controls was positive.

Conclusion: This study using DRVVT lupus anticoagulant, Anticardiolipin and Anti- 32 glycoprotein I assays has found the prevalence of APA in severe pre-eclampsia women seen at Women's Health Hospital, Assiut University to be $6.25 \%$, while none $(0 \%)$ of the controls was positive. These findings suggested that there is a relation between presence of APA and development of severe pre-eclampsia.
\end{abstract}

Key Words: Antiphospholipid antibodies - Severe preeclampsia.

\section{Introduction}

ANTIPHOSPHOLIPID Antibody Syndrome (APS), also known as lupus anticoagulant and Hugh syndrome, is an autoimmune thrombophilic condition with clinical manifestations associated with the presence of Antiphospholipid Antibodies (APA) and Lupus Anticoagulants (LA) in patient plasma. Obstetrical APS is a complex entity that

Correspondence to: Dr. Maha G. Abd El-Kadr, E-Mail: doctormaha1710@gmail.com. may affect both mother and fetus throughout the entire pregnancy with high morbidity [1]

Pre-eclampsia and eclampsia are important complications which may affect pregnant women. Pre-eclampsia may be mild with a systolic blood pressure $>140 \mathrm{mmHg}$ or diastolic pressure $>90$ $\mathrm{mmHg}$ plus proteinuria $>300 \mathrm{mg} /$ day after 20 weeks of gestation or may be severe when systolic blood pressure $>160 \mathrm{mmHg}$ or diastolic $>110 \mathrm{mmHg}$ [2] Eclampsia is a state of convulsions unrelated to cerebral condition, that occurs in pregnant women with severe pre-eclampsia. It occurs in the third trimester or within the first $48 \mathrm{~h}$ after delivery [3]

The clinical criteria of obstetrical APS have been revised in Sidney 2006 and included a history of three consecutive spontaneous miscarriages before 10 Weeks of Gestation (WG), an intrauterine fetal death after $10 \mathrm{WG}$, or premature birth before $34 \mathrm{WG}$ because of severe pre-eclampsia, eclampsia or placental adverse outcomes (intrauterine growth restriction, oligohydramnios). Pregnancy in women with a diagnosis of obstetric APS is at increased risk for placental abruption, hemolytic anemia, elevated liver enzymes, low platelet count (HELLP syndrome) and thrombosis that may be part of a Catastrophic Antiphospholipid Syndrome (CAPS). A previous thrombosis and the presence of a lupus anticoagulant are risk factors for pregnancy failure [4].

APS is diagnosed by presence of APA which comprises a family of antibodies reactive with proteins that have the property of binding to negatively charged phospholipids. They are identified using diverse laboratory procedures based on one of two distinct test procedures, namely solid phase and liquid phase. The solid phase includes anticardiolipin antibodies (ACL) and anti-B2 glycoprotein 
I antibodies (ab p GPI) while liquid phase includes Lupus Anticoagulant (LA) [5].

Antiphospholipid antibodies were found in $15 \%$ of women with Recurrent Pregnancy Loss (RPL) suggesting that APS is one of the most frequent acquired etiology for repeated pregnancy loss. LA was found in $45 \%$ of pregnant women with RPL, however the prevalence of APS in pre-eclampsia and eclampsia is underestimated [6].

\section{Aim of the work:}

- Detection of Anticardiolipin antibodies \& Anti02 glycoprotein I antibodies in pregnant women with severe pre-eclampsia.

- Estimation of the prevalence of APA in pregnant women with severe pre-eclampsia.

\section{Material and Methods}

Study design: This is a hospital based prospective study.

Study area: The study was conducted at Women's Health Hospital, Assiut University. The study was done in the clinical pathology department of Assiut University Hospital in the years from 2014 to 2015.

Study population: There were two groups of participants in this study. Group 1 (case group): Comprised 80 pregnant women with severe preeclampsia recruited from Women's Health Hospital, Assiut University. Group 2 (control group): 20 normal pregnant women without preeclampsia recruited from the antenatal clinic. These were age and parity matched with the test group.

Sample size: A total of 100 women were studied. These included 80 women with severe preeclampsia (case group) and 20, age-parity matched normal on going pregnant women (control group).

Ethical approval: All subjects were informed about the aim of the study and gave their consent.

\section{Inclusion criteria:}

- Newly developed hypertension during pregnancy (after 20 weeks pregnancy).

\section{Exclusion criteria:}

- Patients with preexistent hypertension.

- Gestational diabetes mellitus.

- Preexistent coagulation disorders.

- Previous renal or hepatic disease.

- Patients in labor.
- Hemolytic anemia, elevated liver enzymes and low platelet count (HELLP syndrome).

Sample collection and storage:

Venous blood was collected and divided into:

A- Two ml was collected into EDTA containing tube for complete blood count and reticulocytic count. The blood sample was analyzed within 4 hours after collection.

B- Four ml were collected into plain tube not containing anticoagulant.

- Blood was allowed to clot for 15 minutes at $37^{\circ} \mathrm{C}$ and serum was separated by centrifugation at 3000rpm for 10 minutes.

- Separated serum was inspected to ensure it is clear and non-hemolyzed or lipaemic.

- Random Blood Glucose (RBG), Kidney Function Tests (KFT) and Liver Function Tests (LFT) were done then serum was divided into aliquots and were stored at $-20^{\circ} \mathrm{C}$ till time of assay for anticardiolipin $\operatorname{IgG}, \operatorname{IgM}$ and antip 2glycoprotein I IgG.

C- $4.5 \mathrm{ml}$ blood on citrated tube:

- Venous blood was collected into $0.5 \mathrm{ml}$ (3.2\%) trisodium citrate at a ratio of $9: 1$.

- Plasma was separated by centrifugation at 3000rpm for 10 minutes.

- Prothrombin Time (PT) and activated Partial Thromboplastin Time (aPTT) were done then plasma was stored at $-20^{\circ} \mathrm{C}$ till time of assay for LA screen and LA confirm.

\section{1- Routine investigations:}

- Complete blood count (for patients and control subjects): Was done on (CELL-DYN RUBY) (Abbot-USA).

- Prothrombin Time (PT) and activated Partial Thromboplastin Time (aPTT) were performed on (auto analyzer Sysmex CA- 1500) (SiemensGermany).

- Liver function tests, kidney function tests and RBG (for patients and controls): They were performed on (Cobas Integra 400 plus) (RocheGermany).

\section{2- Specific tests:}

- Lupus anticoagulant tests: Dilute Russel Viper Venom Test (DRVVT) was used to screen for LA. Mixing test was done on samples with prolonged screening results and DRVVT confirm 
test was used for confirmation. LA screen kit and LA confirm kit was provided by Sekisui diagnostics, Germany. An LA screen/LA confirm ratio $>1.2$ was used to define LA positivity.

- Anticardiolipin (IgG/IgM) assay: An ELISA test system for the quantitative measurement of $\operatorname{IgG}$ and IgM class autoantibodies against cardiolipin in human serum or plasma. This product is intended for professional in vitro diagnostic use only. The kit was provided by Organtec diagnostics, Germany.

- Anti-beta-2-GlycoproteinI (IgG): An ELISAbased test system for the quantitative measurement of IgG autoantibodies against beta-2Glycoprotein I in human serum or plasma samples. This product is intended for professional in vitro diagnostic use only. The kit was provided by Organtec diagnostics, Germany.

\section{Statistical analysis:}

Data collected and analyzed by computer program SPSS" Ver. 21" Chicago. USA. Data expressed as mean, standard deviation, number and percentage. ANOVA test and Chi. Square were used to determine significance for categorical variable.

\section{Results}

This study was performed on 80 pregnant inpatient women with severe preeclampsia, who met one or more of the inclusion criteria with age ranging from 20 to 35 years (mean \pm SD $27.13 \pm 5.09$ years) and gestational age ranging from 28 to 36 weeks gestation (mean \pm SD $30 \pm 1.98$ weeks), in the years from 2014 to 2015 . The control group comprises 20 normal pregnant women with age (mean \pm SD $26.33 \pm 4.31$ years) and gestational age (mean \pm SD $31 \pm 2.4$ weeks) of the same range as cases.

This study showed 75 negative cases with the following:

- No past history of pre-eclampsia, abortion or Intra Uterine Fetal Death (IUFD) or thrombosis.

- Negative family history of antiphospholipid syndrome.

- Negative clinical data, examination, CBC, reticulocytic count, RBG, kidney and liver functions.

- Negative screening and specific tests of hemostasis.
While the study showed 5 positive cases with the following:

- Negative past and family history.

- $60 \%$ of them were in their first pregnancy, $20 \%$ in their second pregnancy and $20 \%$ in their third pregnancy.

- They share common clinical data of BP measurement $(160 / 100 \mathrm{mmHg})$, albuminuria $(1000 \mathrm{mg} / \mathrm{dl})$, presence of lower limb edema up to the knee and puffiness of eyelids.

- They have normal RBG, kidney, liver functions, CBC, reticulocytic count and normal screening tests of hemostasis within the normal range.

- They have positive DVV test, confirm and DVV test/confirm ratio showed that LA was strongly present in one patient $(20 \%)(>2)$ and moderately present in four patients $(80 \%)(1.5-2 \%)$.

- They have positive ACL (IgG) in one patient $(20 \%)$ (>2 S.D) and positive ACL (IgM) in four patients $(80 \%)$.

- They have positive Anti B2GP1 (IgG) in all five cases $(100 \%)(>$ mean +2 S.D) .

This study was also done on 20 normal pregnant women known as control group which had the same clinical and laboratory findings as the 75 negative cases.

The present study found the prevalence of APA in severe preeclampsia to be $6.25 \%$ while those of the control population comprising normal pregnant women to be $0 \%$ Fig. (1).

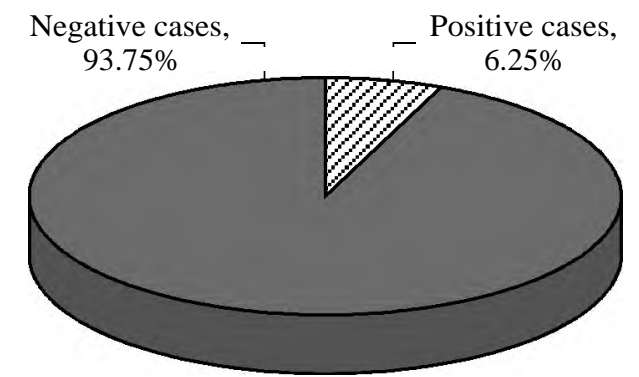

Fig. (1): Prevalence of APA in pregnant women with severe pre-eclampsia.

Table (1) represents a comparison of gravidity in studied groups. This study found that out of normal pregnant women, $50.00 \%$ were primigravidae and $50.00 \%$ were multigravidae. Out of cases primigravidae were $60 \%$ and multigravidae were $40 \%$. 
Table (1): Comparison of gravidity in control (normal pregnant) and severe pre-eclampsia groups.

\begin{tabular}{lcc}
\hline Item & $\begin{array}{c}\text { Normal pregnant } \\
\text { group " } \mathrm{n}=20 "\end{array}$ & $\begin{array}{c}\text { Severe pre-eclampsia } \\
\text { group " } \mathrm{n}=80 "\end{array}$ \\
\hline Primigravida: & "n=10" & " $\mathrm{n}=48 \%$ \\
No. & $50 \%$ & $60 \%$ \\
Percent & & \\
Multigravida: & " $\mathrm{n}=10 "$ & " $\mathrm{n}=32 "$ \\
No. & $50 \%$ & $40 \%$ \\
Percent & & \\
\hline
\end{tabular}

Table (2) represents the (mean $\pm \mathrm{SD}$ ) and the range of demographic data in control (normal pregnant) group in comparison to severe preeclampsia group, with (mean age $\pm \mathrm{SD}$ ) in normal group $(26.33 \pm 4.31)$ years, $(27.13 \pm 5.09)$ years in severe pre-eclampsia with non-significant difference $(p>0.05)$ between the two groups. This table also shows gestational age with (mean \pm SD) $(31 \pm$ 2.4 weeks) in normal group and ( $30 \pm 1.98$ weeks) in severe pre-eclampsia group with non-significant difference $(p=0.278)$ between them.

Table (2): Demographic data in control (normal pregnant) and severe pre-eclampsia groups.

\begin{tabular}{llll}
\hline Item & $\begin{array}{c}\text { Normal } \\
\text { pregnant } \\
\text { group } \\
\text { "n=20" }\end{array}$ & $\begin{array}{c}\text { Severe } \\
\text { pre-eclampsia } \\
\text { group } \\
\text { "n=80" }\end{array}$ & $\begin{array}{c}p \text { - } \\
\text { value }\end{array}$ \\
\hline l-Age "years": & & & \\
Mean \pm SD & $26.33 \pm 4.31$ & $27.13 \pm 5.09$ & $p=0.398$ \\
Range & $(19.0-37.0)$ & $(19.0-37.0)$ & N.S \\
2- Gestational age & $31 \pm 2.4$ & $30 \pm 1.98$ & $p=0.278$ \\
"weeks" & $(28-36)$ & $(28-36)$ & N.S \\
\hline
\end{tabular}

N.S: Non Significant.

Table (3) represents the (mean \pm SD) and the range of clinical data in the two studied groups with highly significant difference of systolic and diastolic blood pressure in severe pre-eclampsia group compared to normal pregnant group ( $p$ $<0.000$ ). As regard Albuminuria and lower limb edema, there were highly significant difference $(p<0.000)$ between the two groups. According to puffiness of eyelids, there was non-significant difference $(p>0.05)$ between the two groups.

Table (4) represents the (mean \pm SD) and the range of screening tests of haemostasis in the two studied groups. There was highly significant difference $(p<0.000)$ in APTT results in severe preeclampsia group compared to normal pregnant group, while moderate significant difference $(p<0.001)$ in PC results between the two groups.
Table (3): Clinical data in control (normal pregnant) and severe pre-eclampsia groups.

\begin{tabular}{|c|c|c|c|}
\hline Item & $\begin{array}{l}\text { Normal } \\
\text { pregnant } \\
\text { group } \\
\text { "n=20" }\end{array}$ & $\begin{array}{c}\text { Severe } \\
\text { pre-eclampsia } \\
\text { group } \\
\text { "n=80" }\end{array}$ & $\begin{array}{c}p- \\
\text { value }\end{array}$ \\
\hline $\begin{array}{l}\text { 1- } S B P(m m H g): \\
\text { Mean } \pm \text { SD } \\
\text { Range }\end{array}$ & $\begin{array}{l}115.60 \pm 5.06 \\
(110-140)\end{array}$ & $\begin{array}{l}160.00 \pm 0.00 \\
(140-160)\end{array}$ & $p<0.000 * * *$ \\
\hline 2- DBP $(\mathrm{mmHg})$ & $\begin{array}{l}75.60 \pm 5.06 \\
(70-80)\end{array}$ & $\begin{array}{l}98.46 \pm 4.88 \\
(90-110)\end{array}$ & $p<0.000 * * *$ \\
\hline $\begin{array}{l}\text { 3- Degree of } \\
\text { albuminuria: } \\
0 \\
1 \\
2 \\
3 \\
4\end{array}$ & $\begin{array}{l}20(100.0 \%) \\
0.0 \\
0.0 \\
0.0 \\
0.0\end{array}$ & $\begin{array}{l}0.0 \\
5 \quad(6.25 \%) \\
35(43.75 \%) \\
33(41.25 \%) \\
7 \quad(8.75 \%)\end{array}$ & $\begin{array}{l}p<0.000^{* * * *} \\
\text { For each }\end{array}$ \\
\hline $\begin{array}{l}\text { 4- Lower limb } \\
\text { edema: } \\
\text { Ankle } \\
\text { Up to knee }\end{array}$ & $\begin{array}{l}20(100 \%) \\
0.0\end{array}$ & $\begin{array}{l}30(37.5 \%) \\
50(62.5 \%)\end{array}$ & $p<0.000 * * *$ \\
\hline $\begin{array}{l}\text { 5- Puffiness: } \\
\text {-ve } \\
\text { +ve }\end{array}$ & $\begin{array}{l}20(100 \%) \\
0.0\end{array}$ & $\begin{array}{l}75(93.33 \%) \\
5 \quad(6.67 \%)\end{array}$ & $p=0.138$ N.S \\
\hline
\end{tabular}

SBP : Systolic Blood Pressure.

DBP : Diastolic Blood Pressure.

N.S $: p>0.05$ Non Significance.

$* *: p<0.05$ significance.

** $: p<0.001$ moderate significance.

$* * *: p<0.000$ highly significance.

Table (4): Screening tests of haemostasis in control (normal pregnant) and severe pre-eclampsia groups.

\begin{tabular}{|c|c|c|c|}
\hline Item & $\begin{array}{l}\text { Normal } \\
\text { pregnant } \\
\text { group } \\
\text { "n=20" }\end{array}$ & $\begin{array}{c}\text { Severe } \\
\text { pre-eclampsia } \\
\text { group } \\
\text { "n=80" }\end{array}$ & $\begin{array}{c}p- \\
\text { value }\end{array}$ \\
\hline $\begin{array}{l}\text { 1- } P T \text { (sec.): } \\
\text { Mean } \pm \text { SD } \\
\text { Range }\end{array}$ & $12.00 \pm 0.00$ & $\begin{array}{l}12.12 \pm 0.52 \\
(11-14)\end{array}$ & $p=0.469$ N.S \\
\hline 2- PC (\%) & $100.00 \pm 0.00$ & $\begin{array}{l}92.44 \pm 9.84 \\
(72-100)\end{array}$ & $p<0.002 * *$ \\
\hline 3- INR & $1.00 \pm 0.00$ & $\begin{array}{l}1.32 \pm 0.28 \\
(1-1.2)\end{array}$ & $p=0.402 \mathrm{~N} . \mathrm{S}$ \\
\hline 4- APTT (sec.) & $\begin{array}{l}28.12 \pm 1.69 \\
(25-30)\end{array}$ & $\begin{array}{l}31.04 \pm 3.16 \\
(25-36)\end{array}$ & $p<0.000 * * *$ \\
\hline
\end{tabular}

PT : Prothrombin Time.

PC : Prothrombin Concentration.

INR : International Normalized Ratio

APTT : Activated Partial Thromboplastin Time.

Table (5) represents the (mean $\pm \mathrm{SD}$ ) and the range of Anticardiolipin (ACL) IgG, IgM and Anti$\beta 2$ glycoprotein1 (A $\beta 2 \mathrm{GP} 1$ ) IgG results in the two studied groups, with non-significant difference $(p>0.05)$ with each ACL (IgG, IgM) and Anti$\beta 2 \mathrm{GP} 1$ (IgG) between the two groups. 
Table (5): Anticardiolipin (ACL) IgG, IgM and Anti$\beta 2$ glycoprotein1 (A $\beta 2 \mathrm{GP} 1)$ IgG in control (normal pregnant) and severe pre-eclampsia groups.

\begin{tabular}{llll}
\hline Item & $\begin{array}{c}\text { Normal } \\
\text { pregnant } \\
\text { group } \\
\text { "n=20" }\end{array}$ & $\begin{array}{c}\text { Severe } \\
\text { pre-eclampsia } \\
\text { group } \\
\text { "n=80" }\end{array}$ & $\begin{array}{c}p \text { - } \\
\text { value }\end{array}$ \\
\hline 1- $A C L$ "IgG" & & & \\
$\quad(U / m l):$ & & & \\
Mean \pm SD & $4.24 \pm 2.40$ & $4.51 \pm 1.56$ & $p=0.728$ N.S \\
Range & $(1-9)$ & $(1-9)$ & \\
2-ACL"IgM" & $3.12 \pm 1.71$ & $3.33 \pm 2.51$ & $p=0.766$ N.S \\
(U/ml) & $(1-6)$ & $(0.5-6)$ & \\
3- Anti & $3.38 \pm 0.71$ & $3.14 \pm 1.20$ & $p=0.117$ N.S \\
$\beta 2$ GP 1 "IgG & $(2.2-4.3)$ & $(1.1-4.7)$ & \\
$\quad$ (U/ml) & & & \\
\hline
\end{tabular}

ACL : Anticardiolipin

Anti $\beta 2 \mathrm{GP} 1$ : Anti- $\beta 2$ glycoprotein 1.

Table (6) represents the (mean $\pm \mathrm{SD}$ ) and the range of DVV confirm and DVV test/confirm results in the two studied groups, with significant difference $(p<0.05)$ in DVV test- confirm between the two groups, but non-significant difference $(p>0.05)$ in DVV test/confirm between the two studied groups.

Although non-significant difference was found between the two groups, yet it was observed that among the group of severe pre-eclampsia, five cases had high level of specific tests of haemostasis. The difference was more than the (mean + 2SD) of the control group and above the upper limit of normal.

Table (6): DVV confirm \& DVV test/confirm in control (normal pregnant) and severe pre-eclampsia groups.

$\begin{array}{cccc} & \text { Normal } & \text { Severe } & \\ \text { Item } & \begin{array}{c}\text { pregnant } \\ \text { group } \\ \text { "n=20", }\end{array} & \text { pre-eclampsia } & p \text { - } \\ & \text { " } \mathrm{n}=80 " & \text { value } \\ \end{array}$

\begin{tabular}{llll}
\hline $\begin{array}{l}\text { 1- DVV test } \\
\text { confirm }\end{array}$ & & & \\
(sec.): & & & \\
Mean $\pm \mathrm{SD}$ & $38.05 \pm 6.47$ & $38.37 \pm 7.41$ & $p=0.458$ \\
Range & $(28.0-59.0)$ & $(29.0-60.0)$ & \\
2- DVV & $0.88 \pm 0.07$ & $0.96 \pm 0.35$ & $p=0.441$ N.S \\
test/confirm & $(0.64-1.0)$ & $(0.47-2.2)$ & \\
\hline
\end{tabular}

Table (7): Age and clinical data in the five positive cases.

\begin{tabular}{|c|c|c|c|c|c|c|c|}
\hline & $\begin{array}{l}\text { Age } \\
\text { (year) }\end{array}$ & $\mathrm{BP}$ & $\begin{array}{c}\text { Gestational } \\
\text { age }\end{array}$ & $\begin{array}{c}\text { No. of } \\
\text { pregnancy }\end{array}$ & $\begin{array}{c}\text { L.L } \\
\text { edema }\end{array}$ & $\begin{array}{l}\text { Puffiness of } \\
\text { eye lids }\end{array}$ & Albuminuria \\
\hline 1 & 28 & $160 / 100$ & 32 weeks & Second & Up to knee & Positive & $1000 \mathrm{mg} / \mathrm{dl}$ \\
\hline 2 & 30 & $160 / 100$ & 36 weeks & Third & Up to knee & Positive & $1000 \mathrm{mg} / \mathrm{dl}$ \\
\hline 3 & 20 & $160 / 100$ & 31 weeks & First & Up to knee & Positive & $1000 \mathrm{mg} / \mathrm{dl}$ \\
\hline 4 & 23 & $160 / 100$ & 31 weeks & First & Up to knee & Positive & $1000 \mathrm{mg} / \mathrm{dl}$ \\
\hline 5 & 24 & $160 / 100$ & 27 weeks & First & Up to knee & Positive & $1000 \mathrm{mg} / \mathrm{dl}$ \\
\hline Range & $(20-30)$ & $(160 / 100)$ & (27-36 weeks) & - & Up to knee & Positive & $(1000 \mathrm{mg} / \mathrm{dl})$ \\
\hline
\end{tabular}

BP: Blood Pressure.

L.L: Lower Limb.

Table (8): CBC data and screening tests of haemostasis in the five positive cases.

\begin{tabular}{|c|c|c|c|c|c|c|c|c|}
\hline & $\begin{array}{c}\text { WBCs } \\
\left(\mathrm{X} 10^{9} / \mathrm{L}\right)\end{array}$ & $\begin{array}{l}\text { HGB } \\
(\mathrm{g} / \mathrm{dL})\end{array}$ & $\begin{array}{l}\text { RET. } \\
(\%)\end{array}$ & $\begin{array}{l}\text { Platelets } \\
\text { (X 109/L) }\end{array}$ & $\begin{array}{c}\text { PT } \\
(\mathrm{sec} .)\end{array}$ & $\begin{array}{l}\mathrm{PC} \\
(\%)\end{array}$ & INR & $\begin{array}{l}\text { APTT } \\
\text { (sec.) }\end{array}$ \\
\hline 1 & 8.9 & 11 & 0.8 & 279 & 12.1 & 89.2 & 1.06 & 30 \\
\hline 2 & 8.3 & 13.2 & 0.7 & 190 & 12 & 100 & 1 & 28 \\
\hline 3 & 12.9 & 10.4 & 0.5 & 180 & 12.7 & 81 & 1.11 & 29 \\
\hline 4 & 7 & 11.9 & 0.8 & 177 & 13 & 77 & 1.1 & 26 \\
\hline 5 & 7.3 & 11.3 & 0.9 & 200 & 11.5 & 98.8 & 1.01 & 32 \\
\hline Range & $(7-12.9)$ & (10.4-13.2) & $(0.5-0.9)$ & $(177-279)$ & $(11.5-13)$ & $(77-100)$ & $(1-1.11)$ & $(26-32)$ \\
\hline
\end{tabular}

WBCs: White Blood Cells.

HGB: Hemoglobin.

RET: Reticulocytes.

Table (9): Relation of results of the five positive cases to the range of normal control and (mean $+2 \mathrm{SD})$.

\begin{tabular}{llllllll}
\hline & 1 & 2 & 3 & 4 & 5 & Mean + 2SD & Range of normal control \\
\hline PT & 12.1 & 12 & 12.7 & 13 & 11.5 & 12.8 & 12 seconds \\
PC & 89.2 & 100 & 81 & 77 & 98.8 & 115.3 & $100 \%$ \\
INR & 1.1 & 1 & 1.1 & 1.1 & 1.01 & 1.14 & 1.0 \\
APTT & 30 & 28 & 29 & 26 & 32 & 38.5 & $(25-30) \mathrm{seconds}$ \\
ACL (IgM) & 10 & 8 & 3 & 8 & 12 & 7.8 & $(1-6) \mathrm{U} / \mathrm{ml}$ \\
ACL (IgG) & 4 & 3 & 28 & 7 & 4 & 10.8 & $(1-9) \mathrm{U} / \mathrm{ml}$ \\
AB2GP1 (IgG) & 5.1 & 5.4 & 5.1 & 5 & 5.2 & 4.9 & $(2.2-4.3) \mathrm{U} / \mathrm{ml}$ \\
DVV test/confirm & 1.8 & 1.8 & 2 & 2 & 2.2 & 1.00 & $(0.64-1.0)$ \\
\hline
\end{tabular}


Subsequently these five cases were separated and analysis of data was done:

Table (7) represents age and clinical data in the five positive cases:

- Their age ranged between 20 and 30 years.

- Their gestational age ranged between 27 and 36 weeks.

- Three patients $(60 \%)$ of them were in their first pregnancy, one patient $(20 \%)$ in its second pregnancy and one patient (20\%) in its third pregnancy.

- They shared common clinical data of BP measurement $(160 / 100 \mathrm{mmHg})$, albuminuria (1000 $\mathrm{mg} / \mathrm{dl}$ ), presence of lower limb edema up to the knee and puffiness of eyelids.

Table (8) represents ranges of CBC data and screening tests of haemostasis in the five positive cases. The 5 positive cases showed normal CBC results, reticulocytic count and screening tests of hemostasis.

Table (9) represents the relation of results of the five positive cases to the normal range and (mean + 2SD):

- They had normal screening tests of hemostasis.

- The results of DVV test/confirm in the five cases: $100 \%$ showed results higher than mean +2 SD These results showed that LA was strongly present in one patient $(20 \%)(>2)$ and moderately present in four patients $(80 \%)(1.5-2 \%)$.

- ACL (IgM): Four patients (80\%) showed results higher than mean $+2 \mathrm{SD}$.

- ACL (IgG): One patient (20\%) showed results higher than mean $+2 \mathrm{SD}$.

- A $\beta 2 \mathrm{GP} 1$ : The five cases (100\%) showed results higher than mean $+2 \mathrm{SD}$.

\section{Discussion}

APS is an autoimmune thrombophilic condition with clinical manifestations associated with the presence of Antiphospholipid Antibodies (APA) and Lupus Anticoagulants (LA) in patient plasma. Obstetrical APS is a complex entity that may affect both mother and fetus throughout the entire pregnancy with high morbidity [1]

The clinical manifestations of APS include vascular thrombosis and pregnancy complications, especially recurrent spontaneous miscarriages, preeclampsia and, less frequently, maternal thrombosis [4].
This study was a preliminary study designed to detect the prevalence of Anticardiolipin antibodies \& Anti-0 2 glycoprotein I antibodies in a cohort of 80 pregnant women with severe pre-eclampsia. The control group comprised 20 normal pregnant women with age and gestational age of the same range as cases. This study was done using DRVVT lupus anticoagulant (LA screen and LA confirm), Anticardiolipin (IgM/IgG) ELISA and Anti-beta2-Glycoprotein I (IgG) ELISA. The results showed that DVV test/confirm ( $p=0.441)$ ACL IgG ( $p=$ $0.728), \mathrm{ACL} \operatorname{IgM}(p=0.76)$ and $\mathrm{A} 02 \mathrm{GP} 1 \operatorname{IgG}(p=$ 0.117 ) with non-significant difference between the two groups. These results were in agreement with Gulj it Kaur et al., [7].

Guljit Kaur et al., [7] had studied 120 patients after 20 weeks of gestation. 60 patients had hypertensive disorder in pregnancy and 60 were normotensive. They were tested for Antiphospholipid antibodies (Anticardiolipin, anti-beta 2 glycoprotein I, phosphatidyl -serine, -inositol, -ethanolamine,choline and sphingomyelin and lupus anticoagulant). They found that APA IgM ( $p=0.081)$ and APA $\operatorname{IgG}(p=0.091)$ with non-significant difference between the two groups.

The subjects included in our study were comparable with respect to age. It was observed that patients in both groups belonged to age group between 20-35 years. There was no patient above the age of 35 years in the two groups. These findings were comparable with those of Lockshin, [8] who conducted that pre-eclampsia and eclampsia were apparently higher in younger women $(<30$ years), while our study was not in agreement with ACOG, [9]; Lain and Roberts, [10] that stated that age $>35$ years is a risk factor for pre-eclampsia.

Our study found that out of normal pregnant women, $50 \%$ were primigravidae and $50 \%$ were multigravidae. Out of cases primigravidae were $60 \%$ and multigravidae were $40 \%$, so the incidence of hypertensive disorder was more among the primigravidae, than the multigravidae. These findings were in agreement with those of Guljit Kaur et al., [7] and Rao et al., [11].

Guljit Kaur et al., [7] found that out of normal cases, $50 \%$ were primigravidae and $50 \%$ were multigravidae. Out of positive cases primigravidae were $56.67 \%$ and multigravidae were $43.33 \%$ and these results were consistent with our study.

The results of our study showed highly significant difference $(p<0.000)$ in APTT results in severe pre-eclampsia group compared to normal pregnant group, while moderate significant difference ( $p$ 
$<0.001)$ in PC results between the two groups. These results were not in agreement with results of Guljit Kaur et al., [7]. They found non-significant values of APTT (>0.005) between the two groups.

In our study, although non-significant difference was found between the severe pre-eclampsia and normal control groups, yet it was observed that among the group of severe pre-eclampsia, five cases had high level of specific tests of haemostasis. The difference was more than the (mean $+2 \mathrm{SD})$ of the control group and above the upper limit of normal.

Our study found the prevalence of APA in severe preeclampsia to be $6.25 \%$ while those of the control population comprising normal pregnant women to be $0 \%$.

The prevalence found in our study was slightly below the rates reported in other studies: Allen et al., [12], Van Pampus et al., [13] and Nwogoh Benedict et al., [14] . Prevalence may differ from one study to another depending on the selection criteria of the study population, sample size studied, the number and type of antiphospholipid antibody assayed, variations in inter-laboratory assays, sensitivity and specificity of the kit used and the threshold use to define APA positivity. It is possible that there may be some variations in the prevalence rates from one race to another.

Van Pampus et al., [13] studied 345 patients with a history of severe preeclampsia, compared with 67 women who remained normotensive during pregnancy. In their study, elevated levels of anticardiolipin antibodies were more common in women with a history of severe preeclampsia compared with controls $(20.9 \%$ versus $7.5 \%, p<0.05)$. One possible explanation for the agreement in the result of our study with those studies is the definition of a "positive test" for anticardiolipin antibodies. Van Pampus et al included a large number of women with low positive titers of anticardiolipin antibodies in the group that was considered to have a positive test.

Nwogoh Benedict et al., [14] studied 50 pregnant women diagnosed as preeclampsia and 50 ageparity matched normal on-going pregnant women. Antiphospholipid antibodies were assayed using Dilute Russell Viper's Venom (DRVV) Lupus Anticoagulant (LA screen and confirm kits) and total Anticardiolipin Antibody (ACA) by Enzyme Linked Immunosorbent Assay (ELISA) kits. The prevalence of APA in their study was $10 \%$ while none $(0 \%)$ of the controls was positive. This was not statistically significant $p$-value $=0.056$. This was in agreement with our study.

The lack of a significant association between APA and preeclampsia found in our study was in agreement with several other studies reported as Dreyfus et al., [15] and Lee et al., [16]. Dreyfus et al., [15] studied 180 women with preeclampsia and 360 controls, and they found that both groups had a similar proportion of women with elevated aCL antibodies. Prevalence of aCL was not elevated, even when only women with severe, early-onset pre-eclampsia were considered. They claimed that APA was not capable of activating the coagulation cascade that already had been activated by another mechanism during preeclampsia such as abnormalities of other thrombophilia markers. Therefore, they consider that these APAs were natural nonpathogenic, innocent autoantibodies.

Our study was also in agreement with several other smaller studies that also failed to demonstrate an association between preeclampsia and elevated levels of aCL antibodies as Uncu et al., [17] and Martinez-Abundis et al., [18].

Our study also agreed with other studies like Duckitt and Harrington, [19]. They conducted a systematic review of three case-control studies (Polzin et al., 1991-Branch et al., 1989-Dreyfus et al., 2001). They reported that women who developed preeclampsia were no more likely to be positive for LA or aCL than those who did not.

Although non-significant difference was found between the severe pre-eclampsia and normal control groups, yet it was observed that among the group of severe pre-eclampsia, five cases had high level of specific tests of haemostasis. The difference was more than the (mean + 2SD) of the control group and above the upper limit of normal. This means that still there is a relation between the presence of APA and development of severe pereclampsia so, APA testing should be considered in women with severe preeclampsia, especially when additional clinical features of APS are present.

\section{Conclusion:}

This study using DRVVT lupus anticoagulant, Anticardiolipin (IgG \& IgM) and Anti-beta-2Glycoprotein I (IgG) assays had found the prevalence of APA in severe pre-eclampsia women seen at Women's Health Hospital, Assiut University to be $6.25 \%$, while none $(0 \%)$ of the controls were positive. Despite non-significant difference in results had been found between normal control and pre-eclampsia groups, relation between pres- 
ence of APA and development of severe preeclampsia still present.

\section{Disclosure of conflict of interest:}

The authors state that they have no conflict of interest.

\section{References}

1- MOVVA S.: Antiphospholipid Syndrome. Medscape Reference. March 24, 2015.

2- AL-JAMEIL N., AZIZ KHAN F., FAREED KHAN M. and TABAS SUM H.: (February 2014). "A brief overview of preeclampsia". Journal of clinical medicine research. 6 (1): 1-7. doi: 10.4021/jocmr1682w. PMID 24400024.

3- WARRINGTON J.P.: Placental ischemia increases seizure susceptibility and cerebrospinal fluid cytokines. Physiol. Rep., Nov. 3 (11), 2015.

4- FISCHER-BETZ R., SPECKER C., BRINKS R. and SCHNEIDER M.: Pregnancy outcome in patients with antiphospholipid syndrome after cerebral ischaemic events: An observational study. Lupus. Oct. 21 (11): 1183-9, 2012.

5- RUFFATTI A., CALLIGARO A., HOXHA A., TREVISANUTO D., RUFFATTI A. and GERVASI M.: Laboratory and clinical features of pregnant women with antiphospholipid syndrome and neonatal outcome. Arthritis Care Res., 62: 302-7, 2010.

6- BARBHAIYA M. and ERKAN D.: Top 10 clinical research developments in antiphospholipid syndrome. Curr. Rheumatol. Rep., Oct. 15 (10): 367, 2013.

7- GULJIT KAUR, SANGEETA PAHWA, AMANBEER KAUR and MADHU NAGPAL: A comparative study of the serum levels of antiphospholipid antibodies in hypertensive disorder of pregnancy and normotensive pregnancy. dx.doi.org/10.18203/23201770.ijrcog20170386, 2017.

8- LOCKSHIN M.D.: Antiphospholipid antibody syndrome. Rheum. Dis. Clin. North Am., 20: 45-59, 1994.

9- ACOG (The American Congress of Obstetricians and Gynecologists) Committee on Obstetric Practice: Diagnosis and management of preeclampsia and eclampsia. Number 33, January 2002. American College of Obstetri- cians and Gynecologists. Int. J. Gynaecol. Obstet., 77: 67-75, 2002.

10- LAIN K.Y. and ROBERTS J.M.: Contemporary concepts of the pathogenesis and management of preeclampsia. JAMA, 287: 3183-6, 2002.

11- RAO A.A. and ANANTHAKRISHNA N.C.: Anticardiolipin antibodies in eclampsia. Int. J. Gynaecol. Obstet., 38: 37-40, 1992.

12-ALLEN J.Y., TAPIA-SANTIAGO C. and KUTTEH W.H.: Antiphospholipid antibodies in patients with preeclampsia. Am. J. Reprod. Immunol., 36: 81-5, 1996.

13- VAN PAMPUS M.G., DEKKER G.A., WOLF H., HUIJ GENS P.C., KOOPMAN M.M., VON BLOMBERG B.M. and BÜLLER H.R.: High prevalence of hemostatic abnormalities in women with a history of severe preeclampsia. Am. J. Obstet. Gynecol., 180: 1146-50, 1999.

14- NWOGOH BENEDICT, AWODU OMOLADE AUGUSTINA, AZIKEN M. EMEFIELE, NWANNADI IKENNA ALEXANDER: Antiphospholipid Antibodies in Women with Preeclampsia, 2014.

15- DREYFUS M., HEDELIN G., KUTNAHORSKY R., LEHMANN M., VIVILLE B., LANGER B., FLEURY A., M'BAREK M., TREISSER A., WIESEL M.L. and PASQUALI J.L.: Antiphospholipid antibodies and preeclampsia: A case-control study. Obstet. Gynecol., 97: 2934, 2001.

16- LEE R.M., BROWN M.A., BRANCH D.W., WARD K. and SILVER R.M.: Anticardiolipin and anti-beta2glycoprotein-i antibodies in preeclampsia. Obstet. Gynecol., 102: 294-300, 2003.

17- UNCU G., OZAN H., KUCUKERDOGAN I. and CANDAN C.: Anticardiolipin antibodies in pregnancy induced hypertension. Eur. J. Obstet. Gynecol. Reprod. Biol., 70: 97-100, 1996

18- MARTINEZ-ABUNDIS E., GONZALEZ-ORTIZ M., CORTES-LLAMAS V. and SALAZAR-PÁRAMO M.: Anticardiolipin antibodies and the severity of preeclampsia-eclampsia. Gynecol. Obstet. Invest., 48: 168-71, 1999.

19- DUCKITT K. and HARRINGTON D.: Risk factors for pre-eclampsia at antenatal booking: Systematic review of controlled studies. B.M.J., 330: 565, 2005. 


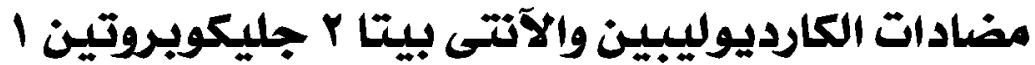

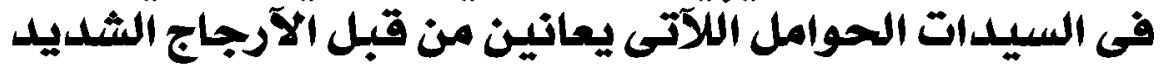

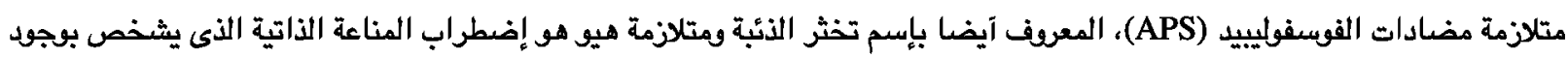

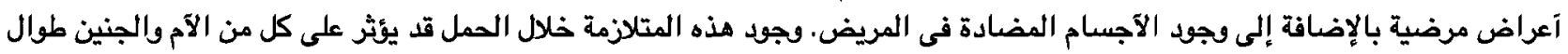

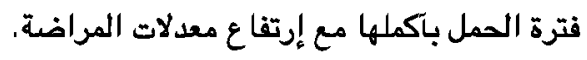

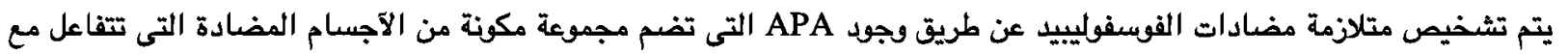

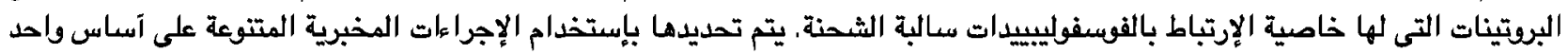

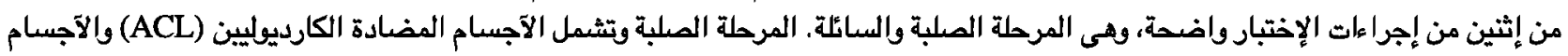

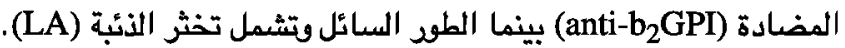
الهدف من العمل:

ا- الكثف عن الآجسام المضادة الكارديولييين (ACL) والآجسام المضادة (anti-b2GPI) فى النساء الصوامل الاتى يعانين من قبل الارجاج الشديد.

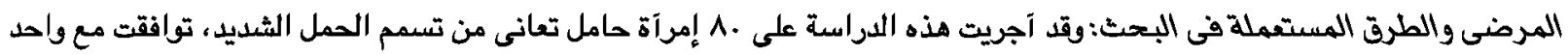

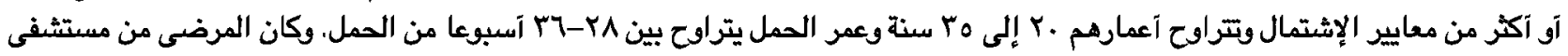

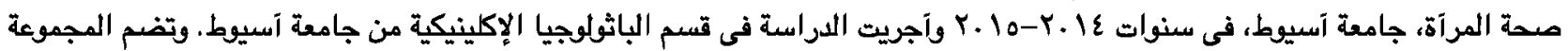

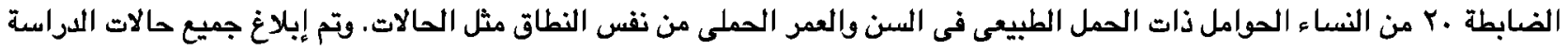

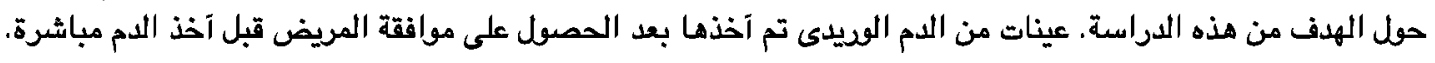

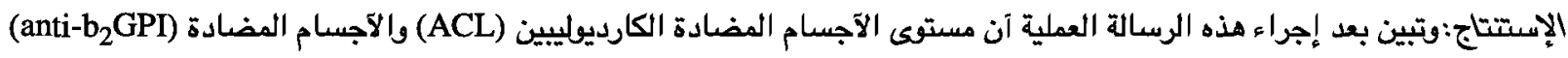

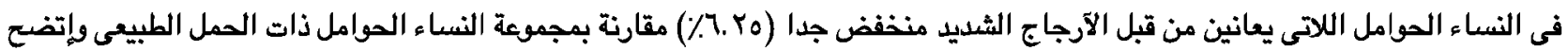

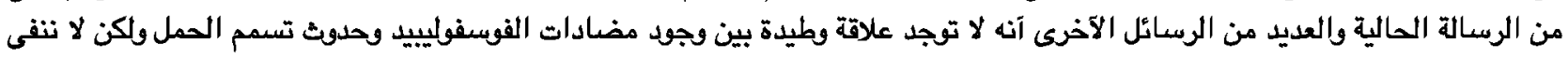

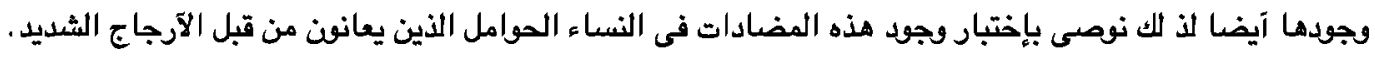

